\title{
UPAYA MENINGKATKAN HASIL BELAJAR IPS PESERTA DIDIK MELALUI PENERAPAN METODE KERJA KELOMPOK KELAS VII PADA SMP PGRI TUMBANG MIRAH KECAMATAN KATINGAN TENGAH
}

\author{
Oleh \\ Sutria Ningsih, ${ }^{*}$ M. Jailani**
}

\begin{abstract}
This study aims: (1) Increasing the activity of IPS VII grade students in SMP Tumbang Mirah, (2) Knowing the learning outcomes of Social Sciences class VII of PGRI Tumbang Mirah Middle School. The method used by researchers is to use the Classroom Action Research (CAR) design. For data collection techniques used were observation and tests with a population of 30 IPS VII grade students of PGRI Tumbang Mirah Middle School. The data analysis technique used is qualitative data analysis and quantitative data analysis. The results showed that: (1) the learning activities of IPS 7th grade students of SMP Tumbang Mirah using more active Group Work Method Implementation, (2) there was an increase in Accounting learning outcomes of IPS VII grade students of SMP Tumbang Mirah using Application of Group Work Methods which shows Accounting learning outcomes in the first cycle obtained an average of $68.5 \%$ with $66.6 \%$ classical completeness and in the second cycle an average of $7.8 \%$ with $93.3 \%$ classical completeness.
\end{abstract}

Keywords: Results of Social Studies Learning, Application of Group Work Methods

\begin{abstract}
ABSTRAK
Penelitian ini bertujuan: (1) Peningkatan akivitas peserta didik kelas VII IPS SMP PGRI Tumbang Mirah, (2) Mengetahui hasil belajar IPS kelas VII SMP PGRI Tumbang Mirah. Metode yang digunakan peneliti adalah menggunakan rancangan Penelitian Tindakan Kelas (PTK). Untuk teknik pengumpulan data yang digunakan adalah observasi dan tes dengan populasi 30 peserta didik kelas VII IPS SMP PGRI Tumbang Mirah. Teknik analisis data yang digunakan adalah analisis data kualitatif dan analisis data kuantitatif. Hasil penelitian menunjukkan bahwa: (1) aktivitas belajar peserta didik kelas VII IPS SMP PGRI Tumbang Mirah dengan menggunakan Penerapan Metode Kerja Kelompok lebih aktif, (2) ada peningkatan hasil belajar Akuntansi peserta didik kelas VII IPS SMP PGRI Tumbang Mirah menggunakan Penerapan Metode Kerja Kelompok yang menunjukkan hasil belajar Akuntansi pada siklus I diperoleh rata-rata $68,5 \%$ dengan ketuntasan klasikal $66,6 \%$ dan pada siklus II rata-rata 7,8\% dengan ketuntasan klasikal 93,3\%.

Kata Kunci: Hasil Belajar IPS, Penerapan Metode Kerja Kelompok
\end{abstract}

PENDAHULUAN

Pendidikan selalu mengalami pembaharuan dalam rangka mencari strukturkurikulum,sistem pendidikan dan metode pengajaran yang efektif dan efesien.Upaya tersebut antara lain 
peningkatan sarana dan prasarana,peningkatan mutu para pendidik dan peserta didik serta perubahan dan perbaikan kurikulum.Pendidikan yang mampu mendukung pembangunan dimasa mendatang adalah pendidikan yang mampu mengembangkan potensi peserta didik,sehingga yang bersangkutan mampu memiliki dan memecahkan problema pendidikan yang dihadapinya. Pendidikan harus menyentuh potensi nurani maupun potensi kompetensi peserta didik.Konsep pendidikan tersebut terasa semakin penting ketika seseorang harus memasuki kehidupan di masyarakat dan dunia kerja,karena peserta didik harus mampu menerapakan apa yang dipelajari di sekolah untuk menghadapi problema yang di hadapi dalam kehidupan sehari-hari maupun yang akan datang.

$$
\text { Menurut Hamalik (2006:45) }
$$
belajar mengandung pengertian terjadinya perubahan dari persepsi dan perilaku, termasuk juga perbaikan perilaku. Belajar adalah suatu kemampuan yang berupa ketrampilan dan perilaku baru sebagai akibat dari latihan atau pengalaman yang diperoleh. Menurut Slameto (2010:79-80) ciri-ciri perubahan tingkah laku dalam belajar antara lain perubahan yang terjadi secara sadar, perubahan dalam belajar bersifat continue, perubahan dalam belajar bersifat positif dan aktif, Perubahan dalam belajar bertujuan atau terarah, dan perubahan mencakup seluruh aspek tingkah laku.

Motivasi adalah perubahan energi dalam diri (pribadi) seseorang yang ditandai dengan timbulnya perasaan dan reaksi untuk mencapai tujuan (Hamalik, 2004:158). Ranah kognitif berkenaan dengan hasil belajar intelektual yang terdiri dari enam aspek,yakni pengetahuan atau ingatan, pemahaman, aplikasi, analisis, sintesisdan evaluasi. Ranah afektif berkenaan dengan sikap yang tediri dari lima aspek, yakni penerimaan, jawaban atau reaksi, penilaian, organisasi, daninternalisasi. Ranah psikomotor berkenaan dengan hasil belajarketrampilan dan kemampuan bertindak. Mengingat pentingnya penilaian dalam menentukan kualitaspendidikan, maka upaya merencanakan dan melaksakan penilaianhandaknya memperhatikan beberapa prinsip dan prosedur penilaian. Menurut Bloom (Sudjana, 2004:22-23) membagi hasil belajarmenjadi 3 ranah yaitu kognitif, afektif dan psikomotor.Ranah kognitifberkenaan dengan hasil belajar intelektual yang terdiri dari enam aspek,yakni pengetahuan atau ingatan, pemahaman, aplikasi, analisis, sintesisdan evaluasi.

Pengertian IPS di tingkat persekolahan itu sendiri mempunyai perbedaan makna, disesuaikan dengan karakteristik dan kebutuhan peserta didik khususnya IPS untuk sekolah menengah pertama (SMP) yaitu gabungan (integrate dari sejumlah mata pelajaran atau disiplin ilmu. Adapun yang termasuk IPS dalam SMP adalah mata pelajaran sejarah, geografi dan ekonomi.Berdasarkan garis - garis Besar Program Pengajaran SLTP (1994).

Menurut Suryosubroto (2009:141) menyatakan bahwa metode adalah cara, 
yang dalam fungsinya merupakan alat untuk mencapai tujuan. Berdasarkan penjelasan tersebut, dapat disimpulkan bahwa metode adalah cara kerja yang bersistem untuk memudahkan pelaksanaan suatu kegiatan guna mencapai tujuan yang sudah ditentukan. Istilah kerja kelompok mengandung arti bahwa peserta didik dalam satu kelas dibagi dalambeberapa kelompok baik kelompok yang kecil maupun kelompok yang besar. Pengelompokan biasanya didasarkakan atas prinsip untuk mencapai tujuan bersama. Kerja kelompok adalah mendasarkan pada suatu ide bahwa peserta didik bekerja sama dalam belajar kelompok dan sekaligus masing-masing bertanggung jawab pada aktivitas belajar anggota kelompoknya, sehingga seluruh anggota kelompok dapat mengusai materi pelajaran dengan baik.

Berdasarkan hasil pengamatan peneliti dan wawancara terhadap guru pada mata pelajaran IPS menjelaskan bahwa, nilai Kreteria Ketuntasan Minimal (KKM) pada mata pelajaran IPS adalah 70 hasil belajar peserta didik pada mata pelajaran IPS rata-rata masih dibawah KKM yakni 50 sampai dengan 55 dari 30 peserta didik hanya ada 8 orang yang mencapai kreteria KKM pada kelas VII SMP PGRI Tumbang Mirah.

Untuk mengetahui permasalahn tersebut, peneliti ingin menggunakan metode keja kelompok dikarenakan dalam metode kerja kelompok ini akan menciptakan suasana yang menyenangkan sehingga peserta didik termotivasi untuk belajar IPS beberapa upaya yang dapat dilakukan guru untuk menarik perhatian dan motivasi peserta didik dalam belajar IPS . Berdasarkan pertimbangan di atas, maka perlu dikembangkan suatu metode pembelajaran yang mampumelibatkan peran serta peserta didik secara menyeluruh sehingga kegiatan belajar mengajar tidak hanya didominasi oleh peserta didik tertentu saja. Selain itu,melalui pemilihan metode pembelajaran tersebut diharapkan sumber informasi yang diterima peserta didik tidak hanya dari guru melainkan juga dapat meningkatkan peran serta (keaktifan siswa) dan hasil belajar dalam mempelajari dan menelaah ilmu yang ada terutama mata pelajaran IPS.Salah satu metode pembelajaran yang melibatkan peran serta peserta didik adalah metode kerja kelompok. Dalam metode kerja kelompok lebih menitik beratkan pada proses belajar pada kelompok dan bukan mengerjakan sesuatu bersama kelompok. Proses belajar dalam kelompok akan membantu peserta didik menemukan dan membangun sendiri pemahaman mereka tentang materi pelajaran. Para peserta didik dalam kelompok belajar bersama-sama dan memastikan bahwa setiap anggota kelompok telah benarbenar menguasai konsep yang telah dipelajari, karena keberhasilan mereka sebagai kelompok bergantung dari pemahaman masing- masing anggota. Dari permasalahan yang terjadi pada SMP PGRI Tumbang Mirah peneliti terarik untuk mengambil judul "Upaya Meningkatkan Hasil Belajar IPS Peserta Didik Melalui Penerapan Metode Kerja Kelompok Kelas VII Pada SMP PGRI 
Tumbang Mirah Kecamatan Katingan Tengah".

\section{METODE PENELITIAN}

Penelitian yang dilakukan menggunakan Penelitian Tindakan Kelas (PTK) yang istilah dalam bahasa inggrisnya adalah Classroom Action Research (CAR). Penelitian Tindakan Kelas adalah pencermatan dalam bentuk tindakan terhadap kegiatan belajar yang sengaja dimunculkan dan terjadi dalam sebuah kelas secara bersamaan (Suyadi, 2011:18). Sedangkan Arikuntoro (2008:20) mengemukakan bahwa tahaptahap dalam Penelitian Tindakan Kelas (PTK) terdiri dari 4 (empat) tahapan penting, meliputi Planning (rencana), Action (tindakan), Observation (pengamatan) dan Reflection (refleksi).

Adapun Subjek penelitian ini adalah pada kelas VII di SMP Swasta Tumbang Mirah, Kecamatan Susukan, Kabupaten Katingan. Terdiri dari 30 siswa laki-laki 17 orang dan 18orang siswa perempuan.

\section{HASIL PEMBAHASAN}

Proses perbaikan pembelajaran dengan menerapkan metode kerja kelompok pada mata pelajaran IPSdi kelas VII SMP PGRI Tumbang Mirah menunjukan adanya peningkatan aktivitas guru dan peserta didik pada siklus I dan pada siklus II. Aktivitas guru pada siklus I dengan memperoleh rata-rata 2,9dari pengamat I (Kepala sekolah), sedangkan dari pengamat II (guru mata pelajaran) aktivitas guru dengan memperoleh rata-rata 2,9 dan pada siklus II aktivitas guru mengalami peningkatan dengan memperoleh rata- rata 3,2 dari pengamat I (Kepala sekolah), sedangkan dari pengamat II (guru mata pelajaran) dengan memperoleh rata-rata 3,2 .

Hasil tes pra tindakan peserta didik memperoleh rata-rata $53,6 \%$ dengan ketuntasan klasikal 26,7\%, sedangkan pada siklus I peserta didik memperoleh rata-rata $68,5 \%$ dengan ketuntasan klasikal 66,6\% akan tetapi belum memenuhi ketercapaian ketuntasan hasil belajar peserta didik secara klasikal, dan pada siklus II menunjukkan adanya peningkatan yaitu,memperoleh rata-rata $7,8 \%$ dengan ketuntasan klasikal 93,3\% telah memenuhi ketercapaian ketuntasan hasil belajar peserta didik secara klasikal sehingga peneliti menggangap pada siklus II ini berhasil. Namun pada hasil tes belajar peserta didik pada pra tindakan sampai post test terdapat tiga orang peserta didik yang tidak tuntas maka ini menjadi hasil kekurangan dalam pelaksanaan penelitian ini.

\section{KESIMPULAN}

Berdasarkan hasil penelitian yang telah dilaksanakan maka dapat disimpulkan bahwa:

1. Aktivitas peserta didik dengan menerapkan metode kerja kelompok peserta didik menjadi lebih aktif dan kerja sama dan mengalami peningkatan disetiap siklus. Siklus I jumlah skor yang diperoleh 19 dengan persentase $79 \%$ kriteria baik dan pada siklus II jumlah skor yang diperoleh peserta didik 20 dengan persentase $83 \%$ kriteria baik. 
2. Adanya peningkatan hasil belajar peserta didik pada mata pelajaran IPS materi Badan usaha, di kelas VIIpada SMP PGRI Tumbang Mirah. Hal ini terlihat dari data hasil belajar peserta didik pada proses pra tindakan memperoleh rata-rata 60,68 dengan ketuntasan klasikal 34,48\%, sedangkan pada siklus I memperoleh rata-rata 76,20 dengan ketuntasan klasikal $65,51 \%$, dan pada siklus II mengalami adanya peningkatan yaitu, memperoleh rata-rata 82,75 dengan ketuntasan klasikal $89,65 \%$.

\section{DAFTAR PUSTAKA}

Arikunto, Suharsimi, (2008). Penelitian

Tindakan Kelas, Jakarta: Bumi Aksara

Hamalik, Oemar. 2006. Proses Belajar Mengajar. Jakarta: Bumi Aksara

Hamalik. 2004. Proses Belajar dan

Pembelajaran. Bandung: CV Yrama Widya

Nana Sudjana. 2004. Dasar-dasar Proses Belajar Mengajar. Bandung: Sinar Baru.

Slameto. 2010. Belajar dan Faktorfaktor yang mempengaruhi belajar. Jakarta:PT. Rineka Cipta

Suryosubroto B. 2009. Proses Belajar Mengajar di Sekolah. Jakarta : PT Rineka Cipta.

Suyadi. 2011. Panduan Penelitian Tindakan Kelas. Jakarta: PT Bumi Aksara. 